\title{
Ethical Practice for the Playwork Practitioner.
}

\author{
David Stonehouse
}

Faculty of Health and Social Care at Edge Hill University, Ormskirk, Lancashire, UK

This paper discusses the importance of ethics for play and playwork practitioners as the sector and work force move towards becoming a recognised profession within the United Kingdom. Exactly what is meant by the term ethics is defined, before moving on to a discussion of two key areas. Firstly the ethical framework known as F.A.I.R. devised by Rowson (2006) and secondly the four ethical principles of Beauchamp and Childress (2013). Throughout links are made to the eight Playwork Principles developed by the Playwork Principles Scrutiny Group, Cardiff in 2005 and endorsed by SkillsActive (2013a).

Key Words: Advocacy, Ethical Framework, Ethical Principles, Ethics, Play, Playwork, Playwork Principles, Veracity.

\section{Introduction}

Playwork is becoming more and more professional and rightly so. Now with the development of the Playwork Register (SkillsActive, 2013b) and with minimum levels of qualifications being required for registration, the question of ethics and how they apply to playwork will become more and more important. The eight Playwork Principles are stated as being "the professional and ethical framework for playwork" (SkillsActive, 2013a). They list eight statements which embody the role and beliefs which playwork practitioners and anyone working with children and young people should have in regards to playwork. However, do playwork practitioners understand what this truly means? Do practitioners recognise how these eight statements can be applied professionally and ethically in their own practice? And importantly, how will playwork practitioners know that they are acting in an ethical playwork way for their children, young people, families, colleagues and the wider communities that they live and work within?

Often when ethical decisions present themselves the issues involved are complex and the way ahead is not always clear. Opposing viewpoints and differences of opinion need to be considered carefully before choosing the right course of action. The aim of this article is therefore to examine and explore what is meant by the term ethics and importantly how this can be applied to everyday playwork practice. Two key ethical frameworks, Rowson's (2006) F.A.I.R. and Beauchamp and Childress's (2013) four ethical principles will be discussed and linked to the Playwork Principles (SkillsActive, 2013a).

\section{What Is Ethics?}

First of all, it is important to define exactly what is meant by the term ethics. Thinking in an ethical way is about striving to do the right thing. It is about making the right choice for the individual playwork practitioner, but more importantly for the children and young people they are working with and for. Hugman (2005, p.160) states that "the purpose of ethics is to pose questions that challenge thought and action." Therefore playwork practitioners through thinking in an ethical way should challenge themselves to consider how they act and think in all situations. Berglund (2007) goes further to state that ethics is a process of reflection. 
Through reflecting upon their actions, playwork practitioners should challenge how they think and what they do. As Stonehouse (2011a) states reflection is about examining practice and why actions and decisions were chosen.

Thinking in an ethical way also allows the playwork practitioner to examine their "life as members of a community, and how we behave and function within society" (Thompson et al., 2006, p.36). As a playwork practitioner, how does our everyday practice impact upon the community and importantly the wider society that we live and work within? How does society and our immediate environment impact upon our role as a playwork practitioner? Do we promote children's rights to play and always act in the best interests of the play users within our community? Are we vocal champions for play? As stated in Playwork Principle No.1 (SkillsActive, 2013a) play "is fundamental to the healthy development and well being of individuals and communities." Considering playwork practice in an ethical way and recognising that membership of the local and wider community, is important in terms of play, will assist the playwork practitioner to be an invaluable resource and advocate for children and young people as well as the communities they live and work within.

Being ethical is not just about reducing our carbon footprint by sourcing our break time snacks from a local supplier. It is not about making sure that the playwork setting always recycles or saves energy. It is not about how the setting impacts upon its immediate neighbours, being considerate to others needs, for example in regards to excessive noise pollution. It is not about considering the impact the setting may have on those service users coming through the doors, for example is the food provided always healthy or with a vegetarian option. Are the dietary requirements of all children and young people met and welcomed? Being ethical is not even about the playwork practitioner being a happy, enthusiastic, positive thinking, forward thinking, passionate about play person all of the time. Though all of these former things are good responsible work place practices, and the latter a good personal and professional mindset, though unrealistic for most normal human beings to behave like this consistently, ethical practice goes much deeper than all this.

Often in the reader's daily lives as well as within playwork practice, choices will have to be made. Sometimes the right decision is obvious and clear cut and there are no alternative view points to consider (Stonehouse, 2012). There is clearly a right and a wrong choice. However, we can often be faced with a dilemma where the right choice is not always clear and where differences of opinion may seem equally valid (Thompson et al, 2006). How does the playwork practitioner attempt to please everybody all of the time? When inevitably this is not possible, how is the best course of action decided upon?

Policies, procedures and even the Playwork Principles (SkillsActive 2013a) do not always inform the playwork practitioner exactly what to do in every situation. As Rowson (2006, p.121-2) states "professionals must constantly make autonomous judgements since even when there are professional rules of thumb or guidelines from advisory committees relevant to their situation they may have to decide how to relate them to their particular circumstances." How a decision is decided upon is often down to the individual playwork practitioner's own ethical viewpoint - what is believed is correct and fair and just at that moment in time whilst adhering to policy. Ethical practice is about deciding on the right way forward, making the right decisions within a set of circumstances, after careful consideration of all the foreseeable potential outcomes and consequences. Of course, the difficulty is that not every outcome is foreseeable and even good intentions and plans do not always turn out right. However, having utilised ethical thinking in the decision making process and having considered seriously all probable and potential outcomes, the decision that is finally arrived at should be the best course of action at that time, given the situation and the information to hand. 
Of course we have all been, and continue to be, affected over time by a large range of influences which help to develop and mould and create our own personal ethical viewpoint. Unless we consciously sit down and consider what these influences may be, they largely go unnoticed and affect us without our knowledge. All life experiences which we have, both good and bad, will have an effect upon how we think, feel and act. They make us the special, unique person that we are. No two people will experience things throughout their lives, in exactly the same way. An individual's beliefs, their upbringing and family influences, their circle of friends, a person's religious education and beliefs, together with their spirituality (and equally as important if a person practices no religion), all assist in the decision making process. The education and training we have received whether it is playwork based or not, will influence how we practice and think. Role models within our workplace will positively influence us and challenge and inspire us to a higher level of practice. Experts and respected authors within the field of playwork and other disciplines, together with the Playwork Principles and playwork organisations all shape and inform our professional practice.

No two people, let alone two playwork practitioners, will have exactly the same ethical beliefs. Hopefully there are a few things which the majority will all hold to be true. On the face of it, it can be stated that everyone accepts and believes that murder is wrong, however some people do commit. If we then bring in discussions around capital punishment and the rightness or wrongness of war, then it starts to become even more unclear. Differences of opinion and debate will ensue. To aid practitioners working within the United Kingdom there are the eight Playwork Principles (SkillsActive, 2013a) which hopefully everyone working within the field of playwork can embrace. However, because play occurs in many different settings and environments and is facilitated by a wide range of different individuals from different professional backgrounds, it is possible and even highly likely that not everyone will be able to accept or even know or agree with part or all of them. The most recent SkillsActive (2015) strategy document reported that employers say there is a gap between the level of skill that they need to run their business and the level of skill that they currently have in their workforce.

The first Playwork Principle (SkillsActive, 2013a) states that "All children and young people need to play. The impulse to play is innate. Play is a biological, psychological and social necessity, and is fundamental to the healthy development and well being of individuals and communities." This first principle clearly states the importance of play to both the individual child and to society as a whole. As Hughes (2012, p.66) states it is a "strong affirmation both of the source of play and its importance to physical and mental health." Therefore from the outset the focus of the playwork practitioner's role should be to assist and facilitate children and young people to play.

The third Playwork Principle (SkillsActive, 2013a) states that "The prime focus and essence of playwork is to support and facilitate the play process and this should inform the development of play policy, strategy, training and education." Everything a playwork practitioner does should have at its centre play. Play comes first, not secondary to other issues.

Therefore to aid professional practice professional and ethical frameworks, such as Rowson's (2006) F.A.I.R. and Beauchamp and Childress's (2013) ethical principles, together with the eight Playwork Principles (SkillsActive, 2013a), can help professionals and playwork practitioners to have a common ground on which to base their ethical decision making. A good playwork practitioner, delivering and facilitating quality play opportunities, should be working within and be guided by these ethical principles and frameworks, using them as a basis for their decision making.

\section{Rowson's (2006) Ethical Framework F.A.I.R.}


Rowson (2006) developed the ethical framework known as F.A.I.R. to assist professionals working across all sectors of society. This mnemonic stands for Fairness, respect for Autonomy, Integrity, and to seek the most beneficial and least harmful consequences or Results. The first part of the framework, fairness, is about providing benefits to all equally, be that healthcare, education, welfare rights, or even play. Can the playwork practitioner truthfully say that the play provision provided is open to all equally, that no child or young person is excluded, either knowingly or as a result of some thoughtless actions? Plowden (2010, p.16) states "disabled children, or those with specific needs, often miss out on the opportunity to play freely in an environment where they feel safe to do so." In the fourth United Kingdom's report to the Committee on the Rights of the Child, the UK's Children's Commissioners reported that for disabled children "fully inclusive play provision has yet to become a reality. In some cases, disabled children are provided with separate and discrete provision that is not freely chosen and leads to them being away from their peers" (AynsleyGreen et al., 2008, p.29).

More recently the KIDS (2013) Playday survey, completed by 952 respondents, reported that only $47 \%$ of people who work with children and young people stated that local services and playspaces were accessible to disabled children and young people. $25 \%$ stated that local services and playspaces were not accessible, with a further $28 \%$ giving no response.

Therefore a quarter of all provision considered in the survey in 2013, does not allow disabled children and young people to access play opportunities and facilities. Playwork Principle No.5 (SkillsActive, 2013a) states that "the role of the playworker is to support all children and young people in the creation of a space in which they can play." As playwork practitioners it is our responsibility, both legally and ethically to ensure that our play service allows all children to freely play within a safe and secure environment. On reflection can the playwork practitioner truthfully assert that all parts of their play service are truly inclusive? Are there activities where disabled children and young people are prevented from accessing? If this is so, then that is clearly not achieving the first part of Rowson's (2006) framework of being treated fairly. It is also not meeting Article 23 of the Convention on the Rights of the Child (UNICEF 1991) which states that disabled children should be active participants in their community.

Rowson (2006) also focuses on the staff team, discussing that the allocation of responsibilities should be done fairly as well. Taking into account people's individual abilities, skills and preferences, these responsibilities should be shared out equally amongst all team members involved. However, do certain members of staff or volunteers within the play setting take on more responsibilities than other members of the team, simply because they are more willing or conscientious? Are there equally staff who avoid responsibilities for an easier time? As the person in charge or senior playwork practitioner within a setting it is our responsibility to recognise this unfairness and share responsibilities out equally. As the manager with staff training and development responsibilities (Stonehouse, 2013), are opportunities for training courses, conference attendance and further education allocated on a fair basis?

The second part of the framework is respect for autonomy. Rowson (2006, p.53) states that professionals should "respect people's autonomy as far as possible within a society in which the legitimate interests of all must be considered." Griffith and Tengnah (2010, p.29) define autonomy as meaning "Self-rule with no control, undue influence or interference from others." Rowson (2006) states that professionals should allow individuals to be in control of decisions about themselves, what they do, what is done to them, and have control over what happens to information about them. As playwork practitioners we need to enable children and young people to be in control of their play, allowing and enabling them to have a voice and to be heard. This links closely with Playwork Principle No.2 (SkillsActive, 2013a). Play is 
freely chosen by the child or young person. It is directed by them, for their own reasons. Playwork practitioners should not interfere with this choice, or try to influence it in any way. The playworker's actions should be to facilitate this free choice and enable it to be realised. Within autonomy, if there is an outcome to the play, then it is whatever has been chosen by the player, and not by the adult. Equally valid is that the play has no outcome, or the outcome is unknown and not considered at the outset. It is play for play's sake. Of course this is all within safe boundaries, and as Rowson (2006) stated the legitimate interests of all must be considered within this.

The third part to the framework is integrity. Rowson (2006, p.53) states that the professional needs "to behave with integrity by acting in accord with the stated or implied values, undertakings and objectives of the profession." This simply means that our actions and personal values should match our professional values. As playwork practitioners do we truly believe in and adhere to the Playwork Principles as guiding our everyday practice. If there is a conflict here then we need to recognise this and act professionally in line with the Playwork Principles and not with our own personal beliefs. If our personal beliefs and values do not match our professional ones then it is time to ask if the playwork practitioner is actually in the right profession. Integrity is about following through with what we believe to be right, both professionally and personally and this can only be achieved if these two beliefs are in harmony.

There is a close connection between integrity and fidelity. Fidelity concerns the relationship that exists between two people, principally the playwork practitioner and the child/young person. Edwards (2009) discusses the fidelity rule as being the commitment between one individual and another. It is about the playwork practitioner being faithful, always striving to keep promises, being trustworthy, showing respect and dignity, and always acting in the other person's best interest (Stonehouse, 2012). Playwork practitioners can demonstrate fidelity through always striving to follow the Playwork Principles, always delivering quality play opportunities to the best of their abilities and knowing and working within the laws, guidelines and policies that govern their practice.

The last part of the framework is seeking the most beneficial and least harmful consequences, or results, for the individual and society (Rowson, 2006). There are two clear aims for the playwork practitioner. Firstly to produce as many benefits as possible, and secondly to avoid causing, and preventing any harm or negative outcomes as much as possible. As playwork practitioners it is important that risk assessments are performed correctly and not merely as an exercise in ticking the boxes. Think through all proposed actions as far as possible so that benefits are identified and increased and possible harmful consequences are removed.

\section{Beauchamp and Childress (2013) Ethical Principles}

Moving on from Rowson's (2006) framework, Beauchamp and Childress (2013) have also developed four ethical principles which can aid professional practice. These are respect for autonomy, beneficence, non-maleficence and justice. The first principle, respect for autonomy is the same as that of Rowson's (2006). However, Beauchamp and Childress (2013) describe it as respecting other people's wishes and then supporting them in carrying out those wishes. We may not always be in agreement with the choices that others make, however we need to support their wishes, if it is safe to do so. Within playwork this means allowing the children to have complete control over their play environment and giving them free choice wherever this is possible. Playwork Principle No.2 (SkillsActive, 2013a) states that "Children and young people determine and control the content and intent of their play, by following their own instincts, ideas and interests, in their own way for their own reasons." This is autonomy in action. It is the role then of the playwork practitioner to support children 
and young people in being able to do this. However, adults working with and alongside children and young people in whatever field and environment, need to make sure that the play that is being facilitated is truly child led. When adults interfere with and become involved 'adulteration' of the playspace can occur (Wragg, 2008). As Sturrock and Else (1998, p.20) state "there is a danger that the play aims and objects of the children become contaminated by, either the wishes of the adult in an urge to 'teach' or 'educate', simply to dominate, or by the worker's own unplayed out material." This is something that needs to be closely guarded against. When this happens the child is no longer determining or controlling their own play but has become subservient to the wishes of the adult.

Loss of autonomy and free choice can also occur when play is designed to meet specific outcomes. The outcomes have been chosen by the adult, not the child, and may well be hidden and not communicated to the child. This can then change the activity from one which was play to one which is now task and possibly work like. The child is no longer participating in the play for their own reasons, but the reasons of the adult. Through this the child's autonomy is reduced and their freedom of choice is taken away.

The second ethical principle is that of beneficence. Berglund (2007, p.12) defines this as "the principle of doing good and providing care to others." Edwards (2009) takes this further by describing it as the promotion of well-being. As playwork practitioners we need to be focussing our practice on always striving to do good whilst promoting the well-being of those children we are working for and with. This cannot always be taken for granted as, from time to time, we all bring negative issues and stress from our personal lives with us into our professional roles. As Playwork Principle No.7 (SkillsActive, 2013a) states, playwork practitioners need to recognise the two way impact that occurs between the adult and the playing child. Playwork practitioners need to make sure that the impact they are having is a positive one, thereby only doing good. They need to guard against bringing their own agendas albeit subconsciously to the play environment.

Playwork Principle No.6 (SkillsActive, 2013a) highlights the importance of playwork practitioners having a sound knowledge and understanding of play and of being reflective in their practice. Having playwork practitioners who are well trained and experienced in delivering play opportunities will help to achieve this principle and to do good. As playwork practitioners, the questions need to be asked, are policies and procedures always followed; what is accepted to be best practice; is the latest research acknowledged and taken on board; is the playwork practitioner properly trained and fully competent to facilitate the play they are providing; is it always of the highest possible standard and quality? If not, then everyone has both a professional duty and an ethical one to acknowledge this and to act upon it.

Playwork Principle No.6 (SkillsActive 2013a) asks the playwork practitioner to reflect upon their practice. Being a reflective playwork practitioner means that experiences are reviewed, through evaluation and analysis, so that lessons can be learnt (Johns, 2009). Reflection is not an activity to be done only when something has gone wrong, but should become the routine normal every day activity of the playwork practitioner. Strengths and weaknesses, positives and negatives can be identified, and through this playwork practice can be evaluated and improved upon (Cottrell, 2008). Through reflective practice, the playwork practitioner can ensure that the ethical principle of doing good can be achieved, both in the immediate here and now, and for the future. By reflecting upon their own practice and then sharing these observations with their playwork colleagues, good and even exemplary practice can be identified and then cascaded to a wider audience, thereby benefitting all (Banks and Gallagher, 2009).

The third ethical principle is non-maleficence. Beauchamp and Childress (2013, p.150) state that this is the obligation "to abstain from causing harm to others." It goes hand in hand with the previous one, beneficence, to do good. As Playwork Principle No.8 (SkillsActive, 
2013a) highlights, playwork practitioners "must balance risk with the developmental benefit and well being of children." We may sometimes deny a child's free choice to prevent harm. This is where our risk assessments come in, which have to be fair and proportional, where our intervention style needs to enable play to be extended within safe but challenging boundaries. As Brussoni et al. (2012, p.3134) state there needs to be a move away from children being "as safe as possible" to one of "as safe as necessary." Through doing this we will be facilitating children and young people to be able to extend their own play and not be constrained unnecessarily by over protective policies and procedures.

The last ethical principle of Beauchamp and Childress (2013) is justice. Justice is closely linked to Rowson's (2006) concept of fairness. Justice is simply defined by Hendrick (2004, p.7) as "equal treatment of equal cases." This is about treating everyone the same. However, do all children within the playwork setting receive equal treatment? At first glance the playwork practitioner may categorically state yes they do, but look closer, do certain children demand more attention because they are more confident than some of their peers? Do those that are loudest get heard first? Justice then is about recognising that some children within the setting may not be having an equal say in decisions, or equal chance at opportunities that should be open to all. Justice for the playwork practitioner then is about being aware of what is going on around them within the environment and being observant and sensitive to the needs of all children and young people.

An equally important issue within justice is we also need to recognise that some children and young people, as well as adults, will require special care and attention over and above what others may need (UNICEF 1991). This is not about disadvantaging those not receiving extra care and attention, but it is rather "about meeting everyone's individual needs fairly" (Stonehouse, 2012, p.250). Giving extra care and attention to some, rather than others who do not require that extra care, is ethical as the playwork practitioner is treating everyone as an individual with individual needs which all need to be met.

\section{Advocacy}

Playwork principle No.4 (SkillsActive, 2013a) states that "playworkers act as advocates for play when engaging with adult led agendas." Pithouse and Crowley (2007) describe advocacy as promoting the overall welfare of children while also challenging injustices. They go on to state it is about any cooperative or individual action which aims to enrich the lives of children (Pithouse and Crowley, 2007); while Bracknell Forest Council (2012, p.1) define advocacy as simply "speaking up for, or acting on behalf of, yourself or another person." Playwork practitioners therefore need to be advocates for the children and young people they come into contact with, so that they are truly equal partners within adult agendas. As Cole-Hamilton (2008) states playwork practitioners need to make children active members together in the decision making process. This is no easy task but one which all playwork practitioners need to strive for. As Davy and Gallagher (2006) state it is the playwork practitioner who needs to ensure that children and young people's voices are heard and they are consulted on all aspects of the play provision they are using. It is about allowing and enabling the child's voice to be heard, and once heard that it is acted upon. Playwork practitioners also have to be aware of any barriers that are put up by adults to hinder this free expression and right of consultation. Lundy (2007) identified that adults often believe children lack the necessary capacity to make a valuable contribution, or that giving children more say in decision making will undermine adult authority, or that consultation with children means too much time is taken. It is the playwork practitioner's responsibility to take down and challenge these barriers. As Article 12 of the UN Convention on the Rights of the Child states the child who is capable of forming his or her own views should have "the right to express those views freely in all 
matters affecting the child, the views being given due weight in accordance with the age and maturity of the child" (UNICEF 1991).

Importantly being an advocate is also about making sure that children and young people are aware of their rights. This is both within play and within the wider society in which they live. They also need to understand how to access those rights fully. As an adult, is the playwork practitioner fully aware of all the rights that they personally have? How less informed might children be? It is important therefore that playwork practitioners become experts in children's rights. As Stonehouse (2011b, p.10) states "It is our role as playworkers to know and understand the rights of children, so that we can accurately advise and support children in gaining their rights." This does not meant that the playwork practitioner needs to be an expert in law. However, they should have a general awareness of law and more importantly a working knowledge of how it directly affects their practice and the children they support.

\section{Veracity}

One concept which is not included in either ethical framework, or within the Playwork Principles (SkillsActive, 2013a), but which is equally important is the idea of veracity. Veracity is simply the concept of truth telling. As Berglund (2007) affirms it is about being open, honest and truthful with people. Sturrock and Else (1998, p.22) in discussing the concept of authenticity propose that playworkers need to be faithful to their feelings within play and that "children will come to trust the "truth' of these responses."

Veracity is also about transferring information in an accurate way, and in a way that the individual person can understand (Edwards, 2009). Article 13 of the UN Convention on the Rights of the Child (UNICEF 1991) talks about the child's right to freedom of expression, but also the right to receive information in a media of their choosing. Playwork practitioners have a duty to listen to the children in their care and to meet their right to receive information that is truthful, honest and open through whichever media the child chooses, so that they can fully understand the information that they have requested. Do adults and even those working within playwork sometimes speak a different language, in the form of technical words or abbreviations which are not explained to children? Through doing this the playwork practitioner is excluding children from receiving information in an understandable format and failing to meet their needs and rights. All information in whatever media it is presented needs to be at the correct level and understanding for the children and families accessing that play provision.

However, as Stonehouse (2012, p. 250) states for playwork practitioners, always telling the truth may not be "an easy principle to maintain when you are asked difficult questions or your answer may be distressing." The playwork practitioner therefore has to be as truthful as they can, while balancing being sensitive to the needs of the child or young person who is asking the difficult question. It is also about the playwork practitioner being self aware and recognising their limitations and seeking help and guidance from more experienced staff, when faced with these difficult questions. It is okay to admit to not knowing what the right answer is, as long as this is done in an open, honest and truthful way.

\section{Conclusion}

In conclusion, we have examined the important role that ethics has upon a playwork practitioner's practice, especially as the work force moves towards becoming a more professionally recognised body of practitioners. Ethical dilemmas occur constantly within everyday life and more importantly within playwork practice. Deciding upon the right course of action, and the right decision for both play and those children and young people who access playwork provision, can often feel like having to choose between the lesser of two 
evils. There may not be an obvious satisfactory answer which meets the expectations of all interested parties. However, the implication of not thinking in an ethical way is that decisions made may well be unsafe and unsatisfactory and could easily be detrimental to everyone involved.

Through being mindful of ethical principles and concepts when faced with dilemmas within playwork, the professional playwork practitioner will be assisted in making the best ethical decisions. Truly embracing and understanding the Playwork Principles (SkillsActive, 2013a), and applying Rowson's (2006) ethical framework as well as Beauchamp and Childress's (2013) ethical principles, will lead to better and more ethically sound decisions being made. This can only lead to more and better quality play opportunities for the children and young people that the playwork practitioner works closely with, and will assist in moving the profession forward.

Further discussion is required within the playwork community to decide whether or not either of these frameworks should be promoted and adopted, or whether a new framework designed by and for playworker practitioners needs to be developed to run alongside and complement the Playwork Principles (SkillsActive, 2013a). It is hoped that this article will prompt discussion and debate upon the subject. 


\section{Notes on contributor}

David Stonehouse is a qualified children's nurse and for the last ten years Senior Lecturer at Edge Hill University. He has been the Programme Leader for the Foundation Degree in Playwork, and is now entering his third year pursuing a PhD at Leeds Beckett University on “the Analytical Exploration of Pre-registration Children's Nurses in Children's Play in Both the Academic and Clinical Setting." He has facilitated workshops for the last five years at the National Playwork Conference in the UK, and was nominated for 'Playwork Writer of the Year' in 2011 and 'Playwork Training Provider of the year' in 2012 at the annual Playwork Awards.

\section{References}

Aynsley-Green, A. Marshall, K. Lewsley, P. \& Towler, K., (2008). UK commissioners' report to the UN committee on the rights of the child. [Internet] Available from: http://www.childcomwales.org.uk/uploads/publications/61.pdf [Accessed 26 August 2015]

Banks, S. \& Gallagher. A., (2009). Ethics in professional life: Virtues for health and social care. Basingstoke: Palgrave McMillan.

Beauchamp, T. \& Childress, J., (2013). Principles of biomedical ethics. Seventh Edition. Oxford: Oxford University Press

Berglund, C., (2007). Ethics for health care. Third Edition. Oxford: Oxford University Press

Brussoni, M. Olsen, L. L. Pike, I. \& Sleet, D. A., (2012). Risky play and children's safety: Balancing priorities for optimal child development. International Journal Of Environmental Research And Public Health. No 9. pp 3134-3148.

Bracknell Forest Council (2012) Speaking Up, Speaking Out, Taking Action: A strategy for commissioning advocacy in Bracknell Forest 2012-2015. [Internet] Available from: http://www.bracknell-forest.gov.uk/advocacy-commissioning-strategy.pdf [Accessed 26 August 2015]

Cole-Hamilton, I., (2008). Children's rights and play. In Brown, F. \& Taylor, C. (eds) Foundations of playwork. Maidenhead: Open University Press. pp 234-37.

Cottrell, S., (2008). The study skills handbook. Third Edition. Basingstoke: Palgrave MacMillan.

Davy, A. \& Gallagher, J., (2006). New playwork: Play and care for children 4 - 16. Fourth Edition. London: Delmar Cengage Learning.

Edwards, S.D., (2009). Nursing ethics: A principle-based approach. Second Edition. Basingstoke: Palgrave Macmillan

Griffith, R. \& Tengnah, C., (2010). Law and professional issues in nursing. Second Edition. Exeter: Learning Matters 
Hendrick, J., (2004). Law and ethics: Foundations in nursing and health care. Cheltenham: Nelson Thornes

Hughes, B. (2012). Evolutionary playwork. $2^{\text {nd }}$ Edition. London: Routledge

Hugman, R., (2005). New approaches in ethics for the caring professions. Basingstoke:

Palgrave Macmillan

Johns, C., (2009). Becoming a reflective practitioner. 3rd Edition. Oxford: Blackwell Publishers

KIDS (2013). Playday Survey Report 2013. [Internet] Available from:

http://www.kids.org.uk/News/kids-playday-survey-report-2013 [Accessed 26 August 2015]

Lundy, L., (2007). 'Voice is not Enough: Conceptualising Article 12 of the United Nations convention on the rights of the child.' British Educational Research Journal. 33 (6), pp 927942.

Pithouse, A. \& Crowley, A., (2007). Adults rule? Children advocacy and complaints to social services. Children and Society. 21, pp 201-213.

Plowden, L., (2010). 'Article 31: a playwork perspective.' Play Today. Winter (68) p 16.

Rowson, R., (2006). Working ethics: How to be fair in a culturally complex world. London: Jessica Kingsley Publishers

SkillsActive (2013a). Playwork principles. [Internet] Available from: http://www.skillsactive.com/PDF/sectors/Playwork_Principles.pdf [Accessed 26 August 2015]

SkillsActive (2013b) SkillsActive launched Register of Playwork Professionals [Internet] Available from: http://www.skillsactive.com/news/skillsactive-launched-register-ofplaywork-professionals\#sthash.cDt0QjsH.dpuf [Accessed 26 August 2015]

SkillsActive (2015) SkillsActive UK Play and Playwork Education and Skills Strategy 20112016 [Internet] Available from: http://www.skillsactive.com/PDF/sectors/PDF_28_Skillsactive_Playwork_Strategy_2011-2016.pdf [Accessed 26 August 2015]

Stonehouse, D., (2011a). 'Using reflective practice to ensure high standards of care.' British Journal Of healthcare Assistants. June. 5(6). pp. 299- 302.

Stonehouse, D., (2011b). 'Advocacy and the playworker.' IP-DiP: For Professionals In Play. Weekly. 23rd December (80) pp. 9-11.

Stonehouse, D., (2012). 'The support worker's guide to ethical practice.' British Journal Of healthcare Assistants. May. 6(5). pp. 249-50.

Stonehouse, D., (2013) 'You are a manager: Should you be a leader?' British Journal of Healthcare Management. August. 19(8). pp. 391-93. 
Sturrock, G. and Else, P. (1998) The playground as therapeutic space: playwork as healing. In: Proceedings of the IPA/USA Triennial National Conference, Play in a Changing Society: Research, Design, Application. June 1998, Colorado. USA

Thompson, I. E. Melia, K. M. Boyd, K. M. \& Horsburgh, D., (2006). Nursing ethics. Fifth Edition. London: Churchill Livingstone Elsevier

UNICEF (1991) United Nations Convention on the Rights of the Child. Svenska: UNICEF Kommitten

Wragg, M., (2008). Guerilla playwork. In Brown, F. \& Taylor, C. (eds) Foundations of playwork. Berkshire: Open University Press. pp 169-73. 